This work is licensed under a Creative Commons Attribution-NonCommercial-NoDerivatives 4.0 International License.

\title{
Spatial and temporal occurrence of pharmaceuticals in UK
}

\section{estuaries}

\section{Sarah Letsinger ${ }^{1}$, Paul Kay $^{1 \star}$, Sara Rodríguez-Mozaz ${ }^{2}$, Marta Villagrassa $^{2}$, Damià Barceló}

Jeanette M. Rotchell ${ }^{3}$

*Corresponding author p.kay@leeds.ac.uk

${ }^{1}$ School of Geography, University of Leeds, Woodhouse Lane, Leeds, LS2 9JT

${ }^{2}$ Catalan Institute for Water Research (ICRA), $\mathrm{H}_{2} \mathrm{O}$ Building, Scientific and Technological Park of the University of Girona, Emili Grahit 101, E-17003, Girona, Spain

${ }^{3}$ School of Environmental Sciences, University of Hull, Cottingham Road, Hull, HU6, 7RX

\section{Abstract}

There is a lack of data on the occurrence of pharmaceuticals in estuaries worldwide, with little understanding of their temporal and spatial variations globally. Ibuprofen, paracetamol, diclofenac, trimethoprim and citalopram were measured in twelve estuaries in the UK. Initially, these compounds were monitored in the Humber Estuary, where samples were taken every two months over a twelve month period in order to assess their spatial and temporal variations. Ibuprofen was found at some of the highest concentrations ever measured in an estuary globally $\left(18-6297 \mathrm{ng} \mathrm{l}^{-1}\right)$, with paracetamol also measured at relatively high concentrations (4 $\left.-917 \mathrm{ng} \mathrm{l}^{-1}\right)$ in comparison to the other compounds. In terms of spatial distribution, a pattern was observed, where highest concentrations were found at a site where wastewater is discharged, whilst compound concentrations were often lower upstream and downstream of this site. The downstream profile of pharmaceuticals differed temporally with concentrations highest downstream when input from wastewater effluent was highest. Eleven further estuaries were sampled around the UK in order to put the occurrence of pharmaceuticals seen in the Humber Estuary into a wider context. Pharmaceutical concentrations in the other estuaries sampled were less than $210 \mathrm{ng} \mathrm{l}^{-1}$, but, again, ibuprofen and paracetamol were found at concentrations higher than other compounds, whereas diclofenac and citalopram were absent from many estuaries. The Humber, which is the receiving environment for the 
This work is licensed under a Creative Commons Attribution-NonCommercial-NoDerivatives 4.0 International License.

sewage effluent for approximately $20 \%$ (13.6 million people) of the population of England, was observed to have the highest overall concentration of pharmaceuticals in contrast to the other estuaries sampled, thereby representing a worst case scenario for pharmaceutical pollution.

Keywords: Pharmaceuticals; Emerging Contaminants; Estuary; Occurrence; Temporal Distribution; Spatial Distribution

\section{Introduction}

Despite the extensive and long-term use of pharmaceuticals, it has only been in the past few decades that interest in pharmaceutical pollution has gained popularity and now hundreds of pharmaceuticals have been detected in the aquatic environment (Hughes et al. 2013; Gaw et al. 2014). Their presence in the aquatic environment is sustained through continuous input from wastewater treatment plants (WWTPs), as well as from improper disposal, agriculture and aquaculture (Godoy et al. 2015). Pharmaceuticals are designed to be biologically active, often at low levels, and their presence in surface water has led to concern over their potential biological effect (Santos et al. 2010). Many pharmaceuticals (e.g. diclofenac and fluoxetine) have been found to illicit a negative response on biota in laboratory exposures at concentrations similar to those found in the aquatic environment (Eades and Waring 2010; Franzellitti et al. 2013; Minguez et al. 2016).

The fate of pharmaceuticals is best understood in the freshwater environment, with input, environmental conditions, biological degradation and sediment-related processes playing a prominent role in their spatial and temporal distribution (Li 2014). Pharmaceuticals often show a decline in concentration downstream from input sources as the result of dilution, degradation and partitioning to sediment (Kunkel and Radkle 2012). However, due to the prevalence of WWTPs, this leads to the continuous input of pharmaceuticals into the environment. As a result, these processes are not enough to sufficiently remove compounds leading to their high detection in the aquatic environment and potentially, transportation into estuaries and coastal waters (Ebele et al. 2017). 
This work is licensed under a Creative Commons Attribution-NonCommercial-NoDerivatives 4.0 International License.

55 Estuaries are receiving waters, often for many rivers, acting as a confluence for contaminants, therefore increasing the potential risk of pharmaceutical pollution in these environments (Ridgway and Shimmield 2002). Estuaries are ecologically important to ecosystem services, providing habitat for many species and acting as an area for recreation and transport (Ridgway and Shimmield 2002). Despite this, few studies have measured the occurrence of pharmaceuticals in estuaries, and those that do, exist typically lack the resolution to determine spatial and temporal patterns (Table 1). Studies which have investigated the spatial and temporal patterns of pharmaceuticals are often locally focused, monitoring only one estuary (for example Tamtam et al., 2012; Hedgespeth et al. 2012; Cantwell et al. 2017) and it is important to determine if any patterns seen are relevant at a wider scale. It is important to examine the fate of these compounds across a wider spatial scale in order to determine whether they pose a risk to the environment.

This study aimed to further contribute to the overall picture of pharmaceutical contamination in estuaries. Five target compounds - ibuprofen, paracetamol, diclofenac, trimethoprim and citalopram were chosen for the present study, based on their prevalent usage and predicted risk to the aquatic environment (National Health Service 2017; Roos et al. 2012). To the author's knowledge, citalopram has not previously been monitored in the estuarine environment (Table 1). Moreover, monitoring of the aforementioned compounds is limited, with some of these measurements dating back almost 15 years. The target compounds were measured every other month over a twelve month period at various sites in the Humber Estuary to determine their spatial and temporal occurrence. In addition, eleven further estuaries, located in other parts of the UK, were selected in order to determine whether concentrations observed in the Humber were representative of other estuaries. 
This work is licensed under a Creative Commons Attribution-NonCommercial-NoDerivatives 4.0 International License.

79 Table 1: Maximum concentrations of ibuprofen, paracetamol, diclofenac and trimethoprim detected in estuaries globally $\left(\mathrm{ng} \mathrm{l}^{-1}\right)$. Citalopram has not previously been monitored in any estuaries.

\begin{tabular}{|c|c|c|c|c|c|c|}
\hline Region & Estuary & $\begin{array}{l}\text { ฮ } \\
\frac{0}{0} \\
\overline{0} \\
=\end{array}$ & 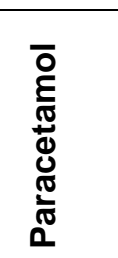 & 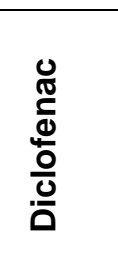 & 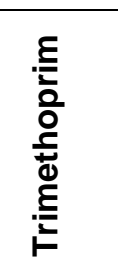 & Reference \\
\hline \multirow[t]{6}{*}{ Asia } & Jiulong, China & 21 & 13 & 11 & & Sun et al. (2016) \\
\hline & Hailing Bay, China & & & & 37 & Chen et al. (2015) \\
\hline & Qinzhou Bay, China & & & 7 & & Cui et al. (2019) \\
\hline & Yangtze, China & & & $<\mathrm{MDL}$ & & Yang et al. (2011) \\
\hline & Yangtze, China & & & & 330 & Zhang et al. (2012) \\
\hline & Yangtze, China & & $<M D L$ & & & Zhao et al. (2015) \\
\hline \multirow[t]{14}{*}{ Europe } & Seine, France & & & & 45 & Tamtam et al. (2008) \\
\hline & Elbe, Germany & 1 & & 1 & & Weigel et al. (2002) \\
\hline & Arade, Portugal & 28 & 88 & 31 & & Gonzalez-Rey et al. (2015) \\
\hline & Douro, Portugal & & & & 16 & Madureira et al. (2010) \\
\hline & Tejo, Portugal & $<M D L$ & 11 & 52 & 8 & Reis-Santos et al. (2016) \\
\hline & Bilbao, Spain & & 440 & 650 & 2046 & Mijangos et al. (2018) \\
\hline & Plentzia, Spain & & 49 & 22 & 6 & Mijangos et al. (2018) \\
\hline & Urdaibai, Spain & & 321 & 35 & 3 & Mijangos et al. (2018) \\
\hline & Belfast Lough, UK & 376 & $<\mathrm{MDL}$ & $<\mathrm{MDL}$ & 32 & Thomas and Hilton (2004) \\
\hline & Mersey, UK & 386 & $<M D L$ & 195 & 569 & Thomas and Hilton (2004) \\
\hline & Tees, UK & 88 & $<\mathrm{MDL}$ & 191 & 17 & Thomas and Hilton (2004) \\
\hline & Thames, UK & 928 & $<\mathrm{MDL}$ & 125 & $<\mathrm{MDL}$ & Thomas and Hilton (2004) \\
\hline & Thames, UK & & & & 19 & Munro et al. (2019) \\
\hline & Tyne, UK & 755 & & 90 & 46 & Thomas and Hilton (2004) \\
\hline North & Charleston Harbour, USA & 8 & 28 & & & Hedgespeth et al. (2012) \\
\hline America & Jamaica Bay, USA & 38 & 156 & & 125 & $\begin{array}{l}\text { Benotti and Brownawell } \\
\qquad(2007)\end{array}$ \\
\hline & Narragansett Bay, USA & & 60 & & 18 & Cantwell et al. (2017) \\
\hline
\end{tabular}


This work is licensed under a Creative Commons Attribution-NonCommercial-NoDerivatives 4.0 International License.

$\begin{array}{cccc}\text { New York Bay, USA } & 162 & 14 & \text { Cantwell et al. (2018) } \\ \text { San Francisco, USA } & & 4 & \text { Klosterhaus et al. (2013) } \\ \text { Sydney, Australia } & 31 & & \text { Birch et al. (2015) }\end{array}$

81

\section{Methods}

\subsection{Study Area}

The Humber Estuary is a macrotidal estuary located in Yorkshire, on the East Coast of England, UK (Figure 1). It is $303 \mathrm{~km}^{2}$, has an average depth of $6.5 \mathrm{~m}$ and is the confluence for the Rivers Ouse, Trent and Hull which pass through some of the largest urban areas in the UK, thus it is the receiving water for approximately $20 \%$ of UK effluent (European Environment Agency, 2019; Table 2). Samples were collected from nine sites along a $65 \mathrm{~km}$ stretch on the North side of the estuary (Figure 1). Two of these were located in the River Ouse: A1 (20 km from Humber) was the furthest upstream and A2 was located less that $1 \mathrm{~km}$ upstream from the confluence with the Humber Estuary. The furthest site upstream in the Humber Estuary (R1) was the receiving site for effluent from Melton WWTP, which serves a population equivalent (PE) of 12,255 (European Environment Agency, 2017). Three sites (R2-R4) were positioned every $2 \mathrm{~km}$ downstream from R1. Three final sites (A3-A5) were located $20 \mathrm{~km}$ from R1 in the lower estuary and $15 \mathrm{~km}$ from the mouth. Further information on site location can be found in Supplementary material S1. The Humber Estuary is an important site for conservation and has been designated as a Special Protection Area (SPA), also containing a Special Area of Conservation (SAC). It is also a vital habitat for many species of international importance, providing habitat for $4.1 \%$ of the red knot (Calidris canutus) and $5.7 \%$ of the common redshank (Tringa tetanus) international populations, and as a result has also been designated as a RAMSAR site (Buck et al. 1997)

Samples were also collected from eleven further estuaries which encompassed a range of estuary types, tidal ranges and sizes (Table 2). The total PE was calculated for the WWTPS 
This work is licensed under a Creative Commons Attribution-NonCommercial-NoDerivatives 4.0 International License.

104 in the catchment area of each estuary (Table 2); further information on the proximity of 105 WWTPs to the sampling sites in each estuary can be found in supplementary material S2. 106 Many of these estuaries have been designated as SACs, SPAs and RAMSAR sites as the 107 result of the sensitive and important species resident to them.

108

109

110

111

Table 2: Information on the type and size of estuaries sampled (Davidson et al.1991). Information on the number of WWTPs and the population equivalent served in 2014 was calculated from an interactive wastewater treatment map (European Environment Agency 2019).

\begin{tabular}{cccccc}
\hline Estuary & Type & Estuary & Tidal & Number of & Total PE \\
& & Area $\left.\mathbf{( k m}^{2}\right)$ & Type & WWTPs in & (000s) \\
& & & & Catchment & \\
Cromarty & Complex & 92.3 & Mesotidal & 3 & 15.6 \\
Forth & Complex & 84.0 & Macrotidal & 33 & 1613.3 \\
Humber & Coastal Plain & 303.6 & Macrotidal & 304 & 13674.7 \\
Mersey & Coastal Plain & 89.1 & Macrotidal & 30 & 3689.7 \\
Portsmouth & Ria & 15.9 & Macrotidal & 2 & 383 \\
Severn & Coastal Plain & 556.8 & Macrotidal & 171 & 6724.4 \\
Solway & Complex & 420.6 & Macrotidal & 20 & 314.9 \\
Tay & Complex & 121.3 & Mesotidal & 12 & 167.6 \\
Tees & Coastal Plain & 13.5 & Macrotidal & 9 & 844.9 \\
Thames & Coastal Plain & 46.5 & Macrotidal & 198 & 16510.5 \\
Tyne & Complex & 7.9 & Macrotidal & 6 & 1092.8 \\
Ythan & Barbuilt & 2.8 & Mesotidal & 1 & 11.2 \\
\hline & & & & & \\
\hline
\end{tabular}


This work is licensed under a Creative Commons Attribution-NonCommercial-NoDerivatives 4.0 International License.

115 Sampling was carried out in the Humber Estuary, UK, every two months from October 2016

116 to August 2017 at sites R1-R4 (Figure 1). Samples were also collected from four additional 117 sites (A1-A2 and A4-A5) in October, February and June, and a further site (A3) in February 118 and June (Figure 1). Sampling was carried out during a high neap tide ( \pm 3 hours) to minimise 119 differences in diurnal concentrations as the result of tides (Lara-Martin et al. 2014). At each 120 site, $3 \times 1 \mathrm{~L}$ of surface seawater were collected in amber glass bottles and temperature, $\mathrm{pH}$ 121 and dissolved oxygen were determined using a $\mathrm{HACH}$ meter and salinity $(0-27 \mathrm{ppt})$ 122 measured with a refractometer (Supplementary material S1). Water samples were kept on 123 ice or in the fridge at $4{ }^{\circ} \mathrm{C}$ and extracted within 48 hours for analysis of pharmaceuticals.

124 2.2.2 UK Wide Monitoring

125 Sampling was carried out in eleven additional UK estuaries in order to provide a wider context 126 for the concentrations of pharmaceuticals seen in the Humber Estuary (Figure 1). Sampling 127 was carried out in August and September 2017 and samples were also collected during high 128 tides ( \pm 3 hours). Within each estuary, sites were chosen in the upper, middle and lower parts 129 of the estuary and $1 \mathrm{~L}$ of water was collected at each of these in amber glass bottles. 130 (Supplementary material S2). Temperature, $\mathrm{pH}$, dissolved oxygen and salinity (0-34 ppt) were determined as above and samples stored and extracted in the same manner (Supplementary material S2). 
This work is licensed under a Creative Commons Attribution-NonCommercial-NoDerivatives 4.0 International License.

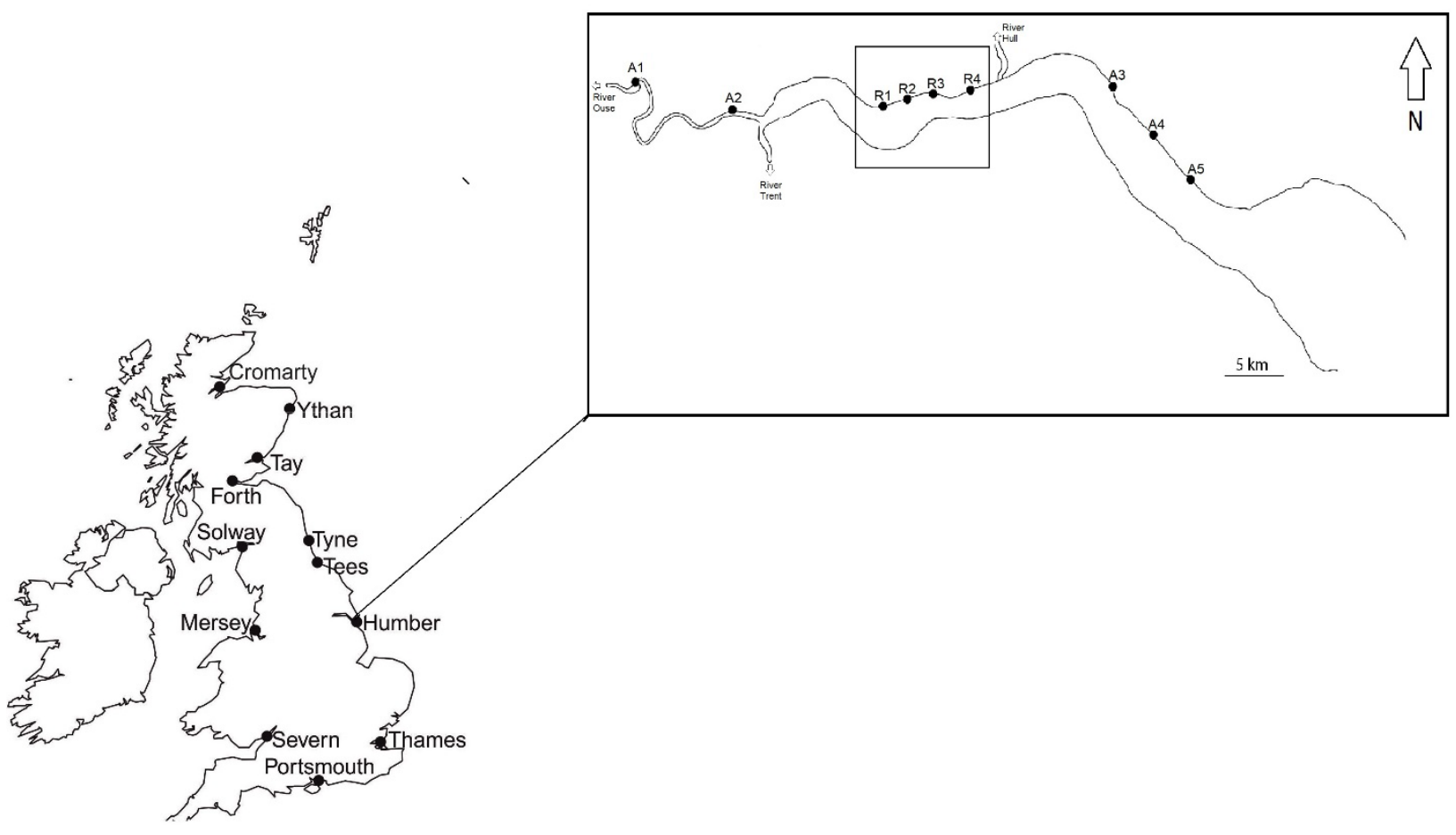

134 Figure 1 Map of field sites for seasonal and UK wide monitoring of selected pharmaceuticals.

135 The sites in the box (R1-R4) indicate those which were sampled every two months. A1-A2 and 136 A3-A5 were sampled every four months.

\subsection{Chemical Analysis}

\section{$139 \quad 2.3 .1$ Study Compounds}

140 Five study compounds - ibuprofen, paracetamol, diclofenac, trimethoprim and citalopram, 141 were chosen for monitoring (Table 3 ). Standards of diclofenac sodium ( $\geq 98.5$ ), acetaminophen 142 ( $\geq 99 \%$ ), citalopram ( $\geq 98)$, ibuprofen ( $\geq 98 \%$ ), and trimethoprim ( $\geq 98 \%$ ) were supplied by Sigma-Aldrich Ltd. (Dorset, UK). 
This work is licensed under a Creative Commons Attribution-NonCommercial-NoDerivatives 4.0 International License.

Paracetamol

Diclofenac

Trimethoprim

Antibiotic

8444

5459

4.52

4.51

296.15

4.2

Citalopram

Antidepressant

9204

4.02

3.74

324.39

9.4

\subsubsection{Solid Phase Extraction}

A composite sample was made, by combining the $3 \times 1 \mathrm{~L}$ surface water samples collected from each site during seasonal monitoring, or from each of the estuaries during the UK-wide survey; they were added together in a $5 \mathrm{~L}$ beaker and stirred vigorously for two minutes. A $500 \mathrm{~mL}$ subsample was taken and filtered through a $0.45 \mu \mathrm{m}$ cellulose filter (Scientific Laboratory Supplies, Hessle, UK) under vacuum. Solid phase extraction was performed on the filtered water samples using Oasis HLB cartridges (Waters Corporation, Massachusetts, USA), which were conditioned with $5 \mathrm{~mL}$ 100\% methanol followed by $5 \mathrm{~mL}$ deionised water at a rate of 1 $\mathrm{mL} \mathrm{min}^{-1}$. The sample was loaded on to the cartridge at a rate of $10 \mathrm{~mL} \mathrm{~min}{ }^{-1}$, during which care was taken not to let the sorbent material dry out. The cartridges were then rinsed with 5 
This work is licensed under a Creative Commons Attribution-NonCommercial-NoDerivatives 4.0 International License. $\mathrm{mL}$ deionised water. The sorbent was dried under vacuum for 15 minutes to remove excess water prior to elution. Elution was performed with $5 \mathrm{~mL} 0.1 \%$ trifluroacetic acid in methanol, followed by a further $5 \mathrm{~mL}$. The eluent was evaporated to dryness using a rotary evaporator $\left(40^{\circ} \mathrm{C}\right.$, speed 7$)$ and reconstituted with methanol: water (10:90).

SPE recovery was evaluated by spiking known concentrations $\left(100,200\right.$, and $\left.1000 \mathrm{ng} \mathrm{l}^{-1}\right)$ of all study compounds into three replicates each of artificial seawater made up to $20 \mathrm{ppt}$ in deionised water (Supplementary material S4). The mean recovery across all concentrations was used to correct the measured environmental concentration (Table 4).

Table 4: Mean method detection limits ( \pm standard deviation), mean method quantification levels $( \pm$ standard deviation) and mean recovery ( \pm standard deviation) of target compounds.

\begin{tabular}{cccc}
\hline Compound & MDL $\left(\mathbf{n g ~ l} \mathbf{~ I}^{-1}\right)$ & MQL $\left(\mathbf{n g ~ \mathbf { I } ^ { - 1 }}\right)$ & Recovery (\%) \\
\hline Citalopram & $0.34(0.25)$ & $1.18(0.85)$ & $43(5.5)$ \\
Diclofenac & $1.77(1.35)$ & $5.91(4.49)$ & $20(11.0)$ \\
Ibuprofen & $1.45(0.41)$ & $4.83(1.38)$ & $73(34.0)$ \\
Paracetamol & $3.28(1.82)$ & $10.93(6.07)$ & $86(34.1)$ \\
Trimethoprim & $0.07(0.04)$ & $0.24(0.12)$ & $63(10.6)$ \\
\hline
\end{tabular}

\subsubsection{UltraperformanceTM-ESI-(QqLIT) MS/MS analysis}

Analysis was carried out according to Gros et al. (2012). Briefly, chromatographic separations were performed with a Waters Acquity Ultra-Performance liquid chromatograph system equipped with two binary pumps systems (Milford, Massachusetts, USA), and coupled to a 5500 QTRAP hybrid quadrupole-linear ion trap mass spectrometer with a turbo ion spray source (Applied Biosystems, Foster Systems, Foster City, CA, USA). Citalopram and trimethoprim were analysed under positive electrospray ionisation (PI) using an Acquity HSS $\mathrm{T}_{3}$ column (50 mm x $2.1 \mathrm{~mm}, 1.8 \mu \mathrm{m}$ particle size) and ibuprofen, paracetamol and diclofenac were analysed under negative ion ( $\mathrm{NI})$ electrospray using an Acquity $\mathrm{BEH} \mathrm{C}_{18}$ column $(5 \mathrm{~mm}$ x $2.1 \mathrm{~mm}, 1.7 \mu \mathrm{m}$ particle size), both from Waters Corporation. 
This work is licensed under a Creative Commons Attribution-NonCommercial-NoDerivatives 4.0 International License.

179 All data acquisition was performed in Analyst 2.1 software. Quantification of analytes was 180 performed by selective reaction monitoring (SRM), monitoring two transitions for each 181 compound as described in Gros et al. (2012). Method detection limits (MDL) and 182 Quantification levels (MQL) were determined for each of the compounds based on a signalto-noise ratio of 3 and 10, respectively (Table 4).

\subsection{Statistical Analysis}

Statistical analysis was performed in R 3.3.1. In order to determine if there was a difference in the occurrence of pharmaceutical between sampling months, concentrations from Melton, North Ferriby, Hessle East and Hessle West were grouped together, as these sites were sampled during all of the sampling periods. A Friedman's Test followed by a Nemenyi posthoc test were conducted using the PMCMR package (Pohlert 2014). All data is presented in graphs created by the ggplot2 package (Wickham 2016).

\section{Results}

\subsection{Humber Estuary}

195 Pharmaceuticals were frequently detected (58 - 97\% of samples for individual study compounds) in the Humber Estuary (Table 5) and concentrations followed the order of ibuprofen $>$ paracetamol>diclofenac $>$ trimethoprim>citalopram. Whilst mean concentrations were in the order of $100 \mathrm{ng} \mathrm{l}^{-1}$ or below, maximum concentrations were approximately 5 to 10 times higher (Table 5; supplementary material S5). Maximum levels of ibuprofen and paracetamol detected in the Humber are the highest concentrations reported in estuaries to date (Table 1). Furthermore, this is the first study to detect in the estuarine environment (Table 1). 
This work is licensed under a Creative Commons Attribution-NonCommercial-NoDerivatives 4.0 International License.

207

Table 5: Pharmaceutical concentrations $\left(\mathrm{ng} \mathrm{l}^{-1}\right)$ in surface water in the Humber Estuary $(\mathrm{n}=38)$ during a 12 month sampling campaign. Values were corrected based on mean recovery values (Table 3). Max $=$ maximum concentration, $\mathrm{SD}=$ standard deviation. Detection rate is the amount of samples above the method quantification limit (MQL).

\begin{tabular}{ccccc}
\hline Compound & $\begin{array}{c}\text { Detection Rate } \\
(\%)\end{array}$ & $\begin{array}{c}\text { Max } \\
\left(\mathbf{n g ~ l}^{-1}\right)\end{array}$ & $\begin{array}{c}\text { Mean } \\
\left(\mathbf{n g ~ l}^{-1}\right)\end{array}$ & SD \\
\hline Ibuprofen & 97.37 & 6297.14 & 665.58 & 1481.49 \\
Paracetamol & 73.68 & 916.88 & 88.65 & 163.66 \\
Diclofenac & 57.89 & 250.8 & 51.44 & 68.29 \\
Trimethoprim & 92.11 & 247.02 & 27.43 & 54.56 \\
Citalopram & 89.47 & 42.93 & 6.39 & 7.66 \\
\hline
\end{tabular}

A general pattern was observed in the occurrence of pharmaceuticals in the Humber surface water, with pharmaceutical concentrations peaking at sampling site R1 (Figures 2) and concentrations upstream (samplings sites A1-A2) and downstream (sampling sites R2-A5) of this site similar to each other. Conversely, this pattern was not consistent in that the chemical concentrations at some of the sampling periods (for instance: paracetamol and diclofenac in June), displayed a reduction in levels downstream (A3-A5). Maximum concentrations were generally seen at sampling site R1 although during some of the sampling periods, they also occurred at sites R2-R4.

Of the three months where all sites were sampled, February had the highest detection rates and concentrations of pharmaceuticals at downstream sites (A3-A5), whilst many of the compounds were absent at these sites in October and June (Figure 2). In contrast, ibuprofen was an exception to this with compounds found at these sites during all of the sampling periods. Citalopram also showed little decline in downstream concentrations in June, and was present at A3-A5, at concentrations similar to or higher than many of the sites further upstream (Figure 2). There appeared to be a relationship between the concentration of pharmaceuticals 
This work is licensed under a Creative Commons Attribution-NonCommercial-NoDerivatives 4.0 International License.

223 at R1 and those seen at the other sites; typically, a higher concentration at R1 resulted in a 224 higher presence at sites further downstream (Figure 2).

225 Sites R1-R4 were sampled more frequently than the other sites, and Trimethoprim was the 226 only compound to show a statistically significant difference between sampling months 227 (Friedman's Test, chi-squared $=14.71, \mathrm{p}<0.05$ ) with concentrations, significantly higher in 228 winter (December and February; 3.29 - $166.54 \mathrm{ng} \mathrm{l}^{-1}$ ), compared to October and the summer 229 months (June and August; $0-142 \mathrm{ng} \mathrm{l}^{-1}$; Figure 3). Nevertheless, the difference was almost 230 significant for ibuprofen $(p=0.054)$ and citalopram $(p=0.051)$. For citalopram, February had 231 the highest concentrations $\left(3.74-42.93 \mathrm{ng} \mathrm{l}^{-1}\right)$, whereas ibuprofen concentrations were higher 232 in April and June (186.37 - 6297.14 ng I-1; Figures 3) in comparison to the other sampling 233 periods. All compounds had lowest mean concentrations in August (Figures 3), with no peaks 234 seen at sampling site R1 (Figure 2). 
This work is licensed under a Creative Commons Attribution-NonCommercial-NoDerivatives 4.0 International License.

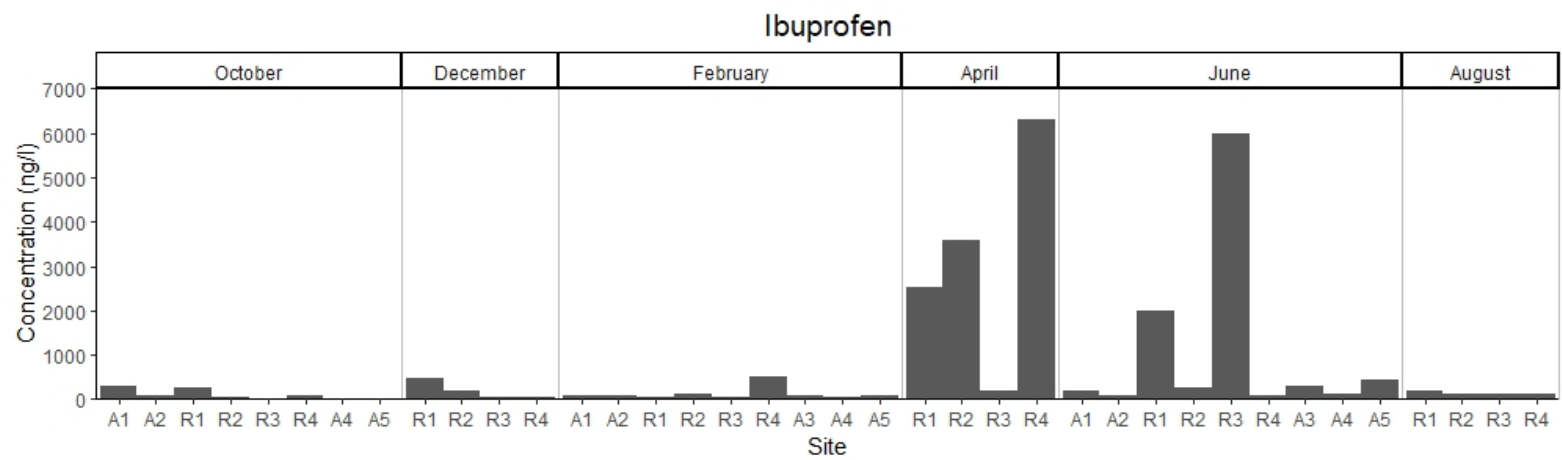

Paracetamol

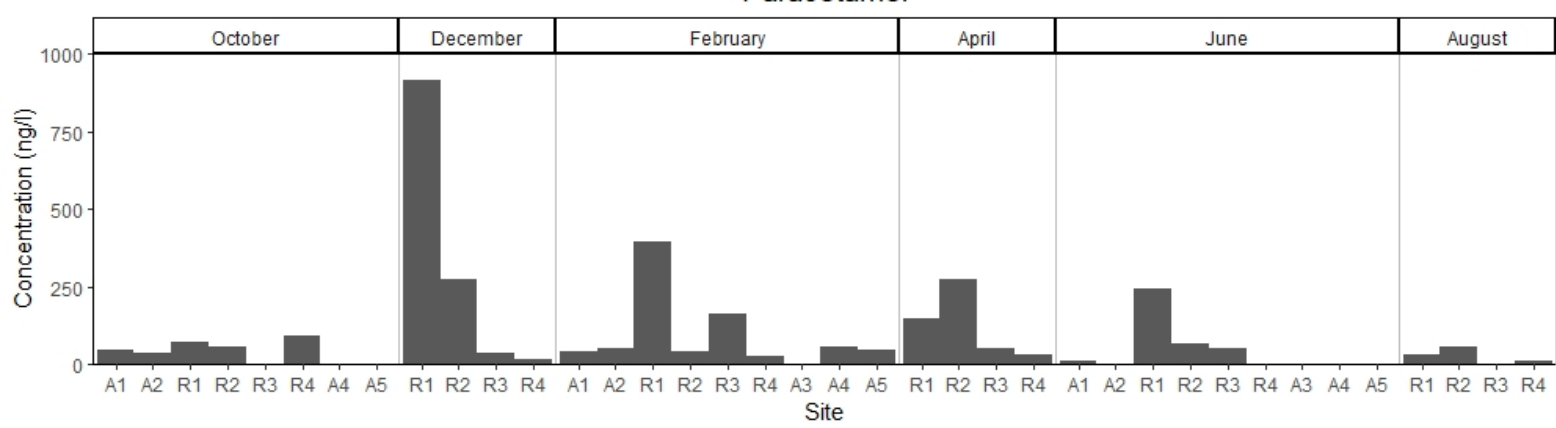

Diclofenac

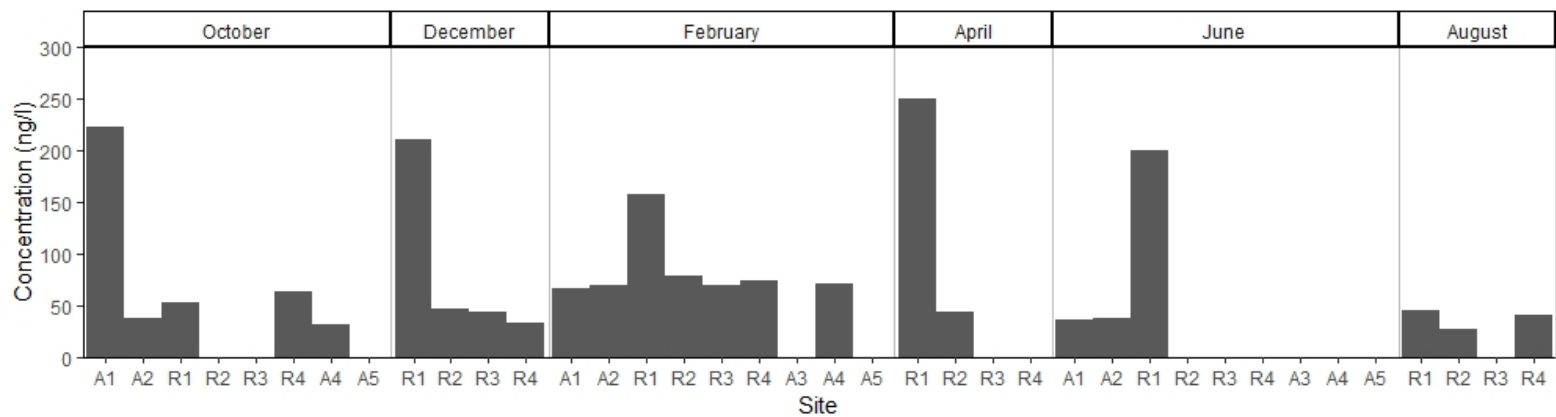

Trimethoprim

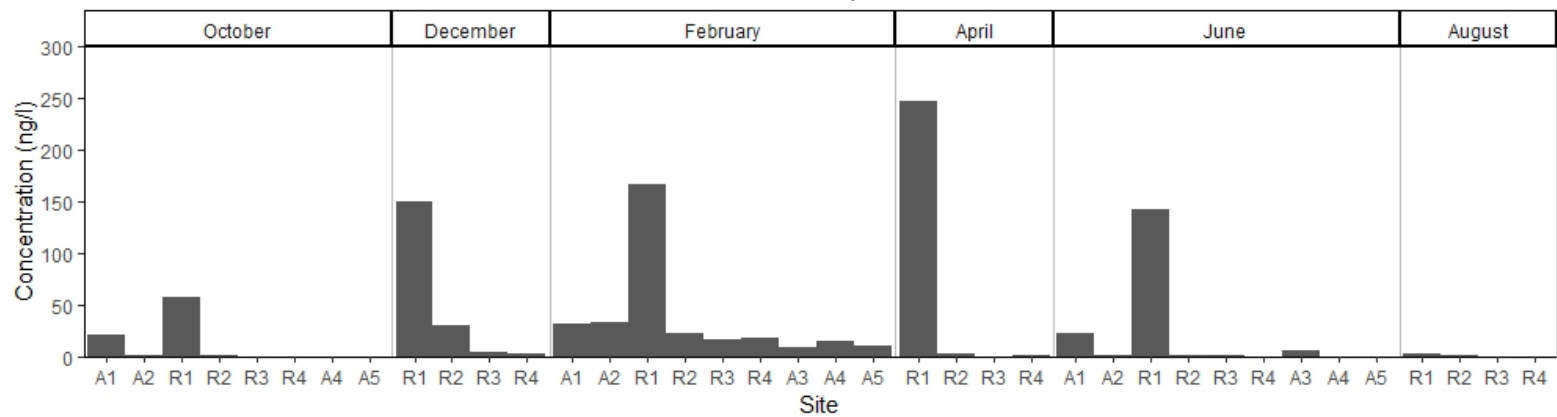

Citalopram

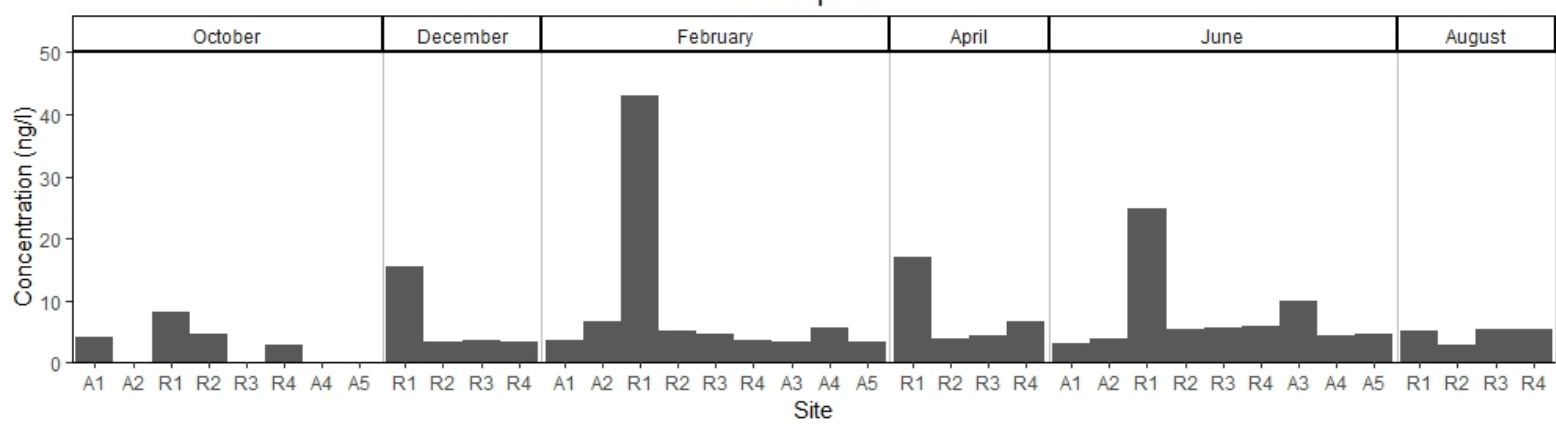


This work is licensed under a Creative Commons Attribution-NonCommercial-NoDerivatives 4.0 International License.

Figure 2 Concentrations of target analytes at nine sites in the Humber Estuary. Values were corrected based on mean recovery values (Table 3). Sites are listed from furthest upstream (A1) to furthest downstream (A5). R1-R4 were sampled every sampling event, whilst the other sites were only sampled in October, February and June, except for A1 which was not sampled in October.
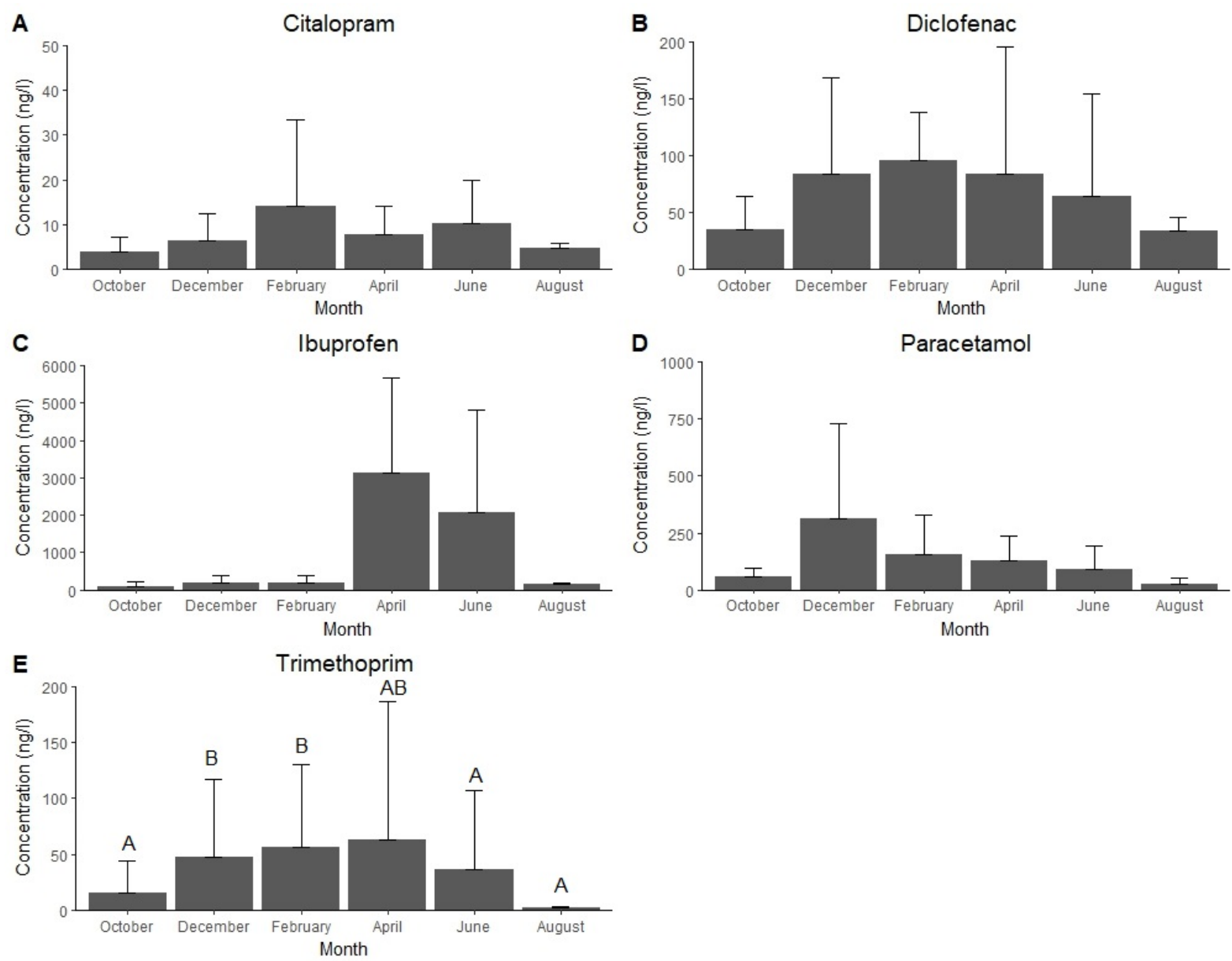

240

E

241 Figure 3 Mean bi-monthly concentrations ( \pm one standard deviation) of (A) Ibuprofen (B) Paracetamol

242 (C) Diclofenac (D) Trimethoprim and (E) Citalopram at the four sites monitored most frequently (R1243 R4). Values were corrected based on mean recovery values (Table 3). Letters denote statistically 244 significant difference (Friedman's Test).

\subsection{UK-wide sampling}

247 Pharmaceuticals were detected in all of the estuaries sampled around the UK but only at concentrations in the low ng $\mathrm{l}^{-1}$ range and were generally present at concentrations lower than those detected in the Humber Estuary (Figure 4). The order of pharmaceuticals were similar 
This work is licensed under a Creative Commons Attribution-NonCommercial-NoDerivatives 4.0 International License.

to that found in the Humber (ibuprofen>paracetamol>diclofenac>citalopram>trimethoprim), except trimethoprim was found at lowest concentrations (supplementary material S6). Ibuprofen and trimethoprim were present in all of the estuaries sampled, whereas diclofenac was only detected in two of the other estuaries, the Cromarty and Thames (Figure 4). The Thames and Humber were the only estuaries to contain all of the compounds. The Humber had the overall highest concentration of pharmaceuticals, and only the Cromarty and Tay had a total concentration of pharmaceuticals over $200 \mathrm{ng} \mathrm{l}^{-1}$ (Figure 4).

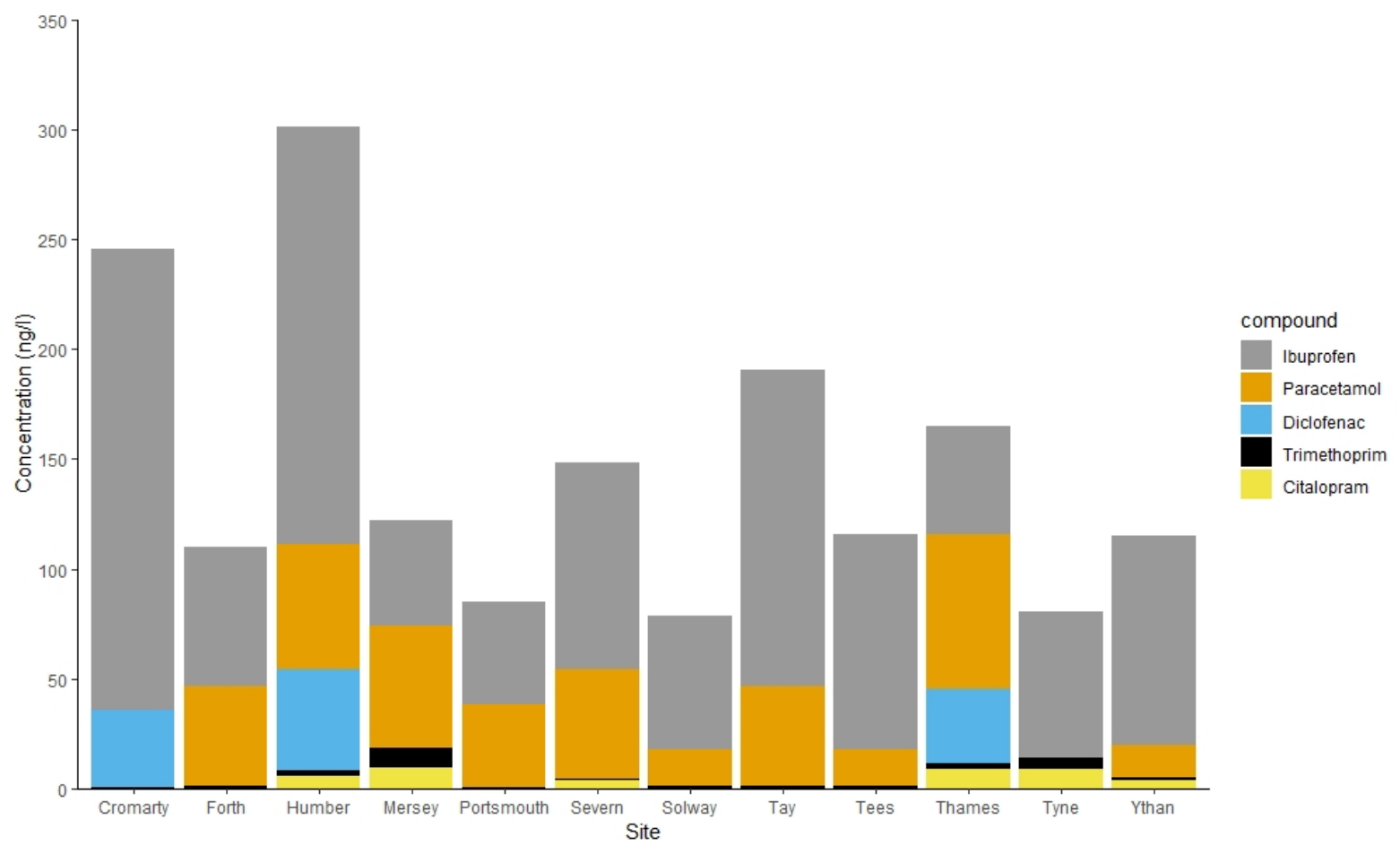

Figure 4 Concentrations of citalopram, diclofenac, ibuprofen, paracetamol and trimethoprim across eleven estuaries in the UK. Concentrations have been corrected for recovery (Table 3). Concentrations reported for the Humber are maximum concentrations measured in August, when the wider UK survey was undertaken.

\section{Discussion}

Most monitoring studies to date have been carried out in freshwater systems as it was originally thought that estuaries and coastal waters would dilute compounds so that they would 
This work is licensed under a Creative Commons Attribution-NonCommercial-NoDerivatives 4.0 International License.

267 be undetectable (Fabbri and Franzellitti 2016). Despite this hypothesis, pharmaceutical contamination was found to be widespread as all of the estuaries monitored contained at least three of the target analytes at levels of a similar magnitude to those found in the freshwater environment, and higher than those measured in many other estuaries (Hughes et al. 2013; Table 1). The levels of pharmaceuticals detected in this study, contribute to the overall picture on pharmaceutical pollution and add to the growing evidence that it is a global issue (aus der Beek et al. 2016). Our work indicates that the limited monitoring carried out to date may not have captured peak concentrations that occur in these environment and clearly highlights that further work is needed.

Ibuprofen was detected at the highest concentrations and in all of the estuaries sampled, with its occurrence not only exceeding levels detected in other estuaries (Table 1), but also those seen in river water both in the UK (Barbara Kasprzyk-Hordern et al. 2008; Kay et al. 2017; Burns et al. 2017, 2018), as well as globally (Hughes et al. 2013). Ibuprofen has only been measured in 7 estuaries previously, with maximum concentrations all under $100 \mathrm{ng} \mathrm{l}^{-1}$ (Table 1). Further monitoring studies should include ibuprofen as a priority to determine if high concentrations seen in the UK are similar to those elsewhere.

Concentrations of paracetamol, diclofenac and trimethoprim were similar to those seen in other global estuaries, with mean concentrations less than $100 \mathrm{ng} \mathrm{l}^{-1}$ (Table 1). Whilst maximum concentrations of paracetamol were similar to those detected in rivers (Barbara Kasprzyk-Hordern et al. 2008; Burns et al. 2017), concentrations of diclofenac and trimethoprim were considerably lower (Hughes et al. 2013; Nakada et al. 2017). In the present study, water samples were collected at high tide, when concentrations would be expected to be lowest, so it is possible that these levels could be higher at other points in the tidal cycle (Yang et al. 2016). This is the first study to measure the occurrence of citalopram, however concentrations were low and did not exceed $50 \mathrm{ng} \mathrm{l}^{-1}$. These low concentrations are in agreement with previous studies which have monitored citalopram in rivers (Hughes et al. 
This work is licensed under a Creative Commons Attribution-NonCommercial-NoDerivatives 4.0 International License.

293

294

295

296

297

298

299

300

301

302

303

304

305

306

307

308

309

310

311

312

313

314

315

316

317

318

2013). Despite these low concentrations, PNECs for citalopram are below this (Minguez et al. 2016).

Whilst an overall widespread occurrence of pharmaceuticals was seen in the UK, patterns in their spatial and temporal distributions within and between estuaries were observed.

\subsection{Humber Estuary}

\subsubsection{Spatial Variation}

It is generally expected that pharmaceutical concentrations will decrease downstream due to physical processes in an estuary leading to their breakdown and removal (Daughton 2016). The spatial pattern of pharmaceutical occurrence in the Humber Estuary followed this pattern to a degree; peak concentrations were found in the middle of the estuary, particularly at R1, where samples were collected next to an outlet from a wastewater treatment plant (WWTP), indicating that WWTPs could be a significant source of pharmaceuticals in the Humber Estuary. Input from WWTPs has been attributed as the largest source of pharmaceutical pollution in the aquatic environment (Caldwell 2016). In some cases maximum concentrations were detected outside of this site; in April and June, maximum concentrations for paracetamol and ibuprofen occurred at sites R2-4. It is difficult to determine what caused these peaks as composite sampling can lead to uncertainty in the representativeness of samples in cases such as this, however these sites are within $6 \mathrm{~km}$ from R1, so it is possible that the large increases seen at these sites are still due to input at R1, and fluctuations of concentrations between these sites are the result of sampling timing or within sample variation (Ort et al. 2010). The site (R4) which showed the highest levels $\left(6.2 \mu \mathrm{gl}^{-1}\right)$ of ibuprofen was also $7 \mathrm{~km}$ upstream from the confluence of the River Hull. Transport of pharmaceuticals from this tributary upstream during high tide could also account for the increases seen. The River Trent, located near the confluence with the Ouse (Figure 1), will also account for the addition of further pharmaceuticals. Inputs of pharmaceuticals in other studies have also been attributed 
This work is licensed under a Creative Commons Attribution-NonCommercial-NoDerivatives 4.0 International License.

to other sources such as improper disposal, leaching from landfills or through veterinary usage and subsequent runoff of these compounds into the aquatic environment, which could account for these differences. (Bound and Voulvoulis 2005; Ebele et al. 2017).

Dilution plays a key role in the fate of pharmaceuticals in the aquatic environment and the decrease in concentrations after R1 is presumably caused by dilution away from the input source (Baker and Kasprzyk-Hordern 2013). Decline of pharmaceutical concentrations downstream the estuary was observed more in some compounds than others, and as a result, is unlikely to be fully explained by dilution. Degradation of pharmaceuticals has been found to be a significant factor affecting the fate of pharmaceuticals and could account for these differences (Caracciolo et al. 2015). Citalopram experienced the lowest decrease in concentration downstream, and was typically the same concentration, or higher at A5 than A1, which could be explained by the low degradation which has been observed in other studies (Metcalfe et al. 2010; Styrishave et al. 2011). Ibuprofen, paracetamol and trimethoprim also showed little decline in concentration beyond initial dilution after R1, which is consistent with what has been seen at other sites. These compounds have been found up to $10 \mathrm{~km}$ downstream from a WWTP (Bendz et al. 2005, Kay et al. 2016, Burns et al. 2018), and trimethoprim has even been found $200 \mathrm{~km}$ downstream from an WWTP (Tamtam et al. 2008). Further WWTPs are located within the estuary (European Environment Agency, 2019) which could also account for this lack in decline. Diclofenac on the other hand, was not detected at A3 or A5 during any of the sampling periods, but was found at A4. The downstream decline of diclofenac has been found to be variable, with some studies finding it to be more persistent than others (Bendz et al. 2005; Wilkinson et al. 2017). Removal of compounds through degradation and sorption to sediment has been found to be highly dependent on environmental conditions and sediment type.

\subsubsection{Temporal Variation}

Seasonal differences of pharmaceuticals have been observed in a number of studies and these are often attributed to changes in usage and local environmental conditions (Golovko et 
This work is licensed under a Creative Commons Attribution-NonCommercial-NoDerivatives 4.0 International License.

al. 2014b; Moreno-González et al. 2014). Trimethoprim was the only compound to show significant temporal differences in concentrations (at sites R1-R4), with average winter concentrations over double that of those during the summer months. Previous studies have explained the seasonal occurrence of antibiotics in winter due to their higher usage in those months to treat seasonal infections (Verlicchi and Zambello 2016). The temporal differences seen in the occurrence of trimethoprim in the Humber Estuary appeared to follow this pattern, as prescriptions were highest in October 2016 to March 2017 and lowest in August 2017 (Supplementary material S4). Trimethoprim has been observed to have higher winter concentrations in some studies (Golovko et al. 2014b) but not in others (Burns et al. 2018). Burns et al. (2018) found higher levels of trimethoprim during spring in the Ouse (upstream from A1), which was attributed to hydrological differences seen between the seasons sampled. As a result, it is likely that the temporal differences in trimethoprim are the result of different site specific conditions or daily variations. Temporal variations in other studies have also been explained by lower temperatures, leading to lower degradation (Golovko et al. 2014a), however, input at R1 was highest in April. The other target compounds have exhibited in other locations, but did not in the Humber. Paracetamol, for instance, has been detected at high concentrations in spring in some rivers but winter in others, whilst other studies found no temporal variations (Paíga et al. 2016; Ma et al. 2017; Burns et al. 2018).

Temporal variations in the downstream pattern of pharmaceuticals were also observed, with the greatest variation seen at the sites furthest downstream (A3-A5). Pharmaceuticals were mostly absent from these sites in October, with the exception of ibuprofen, where concentrations were reduced. Sampling at high tide could account for the absence of these result of timing of effluent discharges from WWTPs and combined sewer overflows (CSOs), as well as variations in wastewater as the result of consumption patterns (Xu et al. 2007). To an extent, there was a pattern in the presence of compounds at R1 consistent with those seen 
This work is licensed under a Creative Commons Attribution-NonCommercial-NoDerivatives 4.0 International License.

downstream the estuary, so it is possible that the temporal variations could be the result of these daily variations, instead of conditions seen seasonally. The concentration of pharmaceuticals at R1 were lowest in October and the low input could, in part, account for the absence of compounds seen at sites furthest downstream (A3-A5). Likewise, concentrations for the majority of compounds were highest at R1 during February where concentrations were highest at sites furthest downstream (A3-A5). This is further evidence that there is a difference in input from WWTPS. R1 is not the only site at which wastewater is discharged, but if these other sites exhibit the same temporal variations, then it could explain the differences observed in concentrations at A3-A5. WWTP removal has been found to be less efficient during the winter time due to lower temperatures and decreased biodegradation, leading to higher concentrations in effluent (Vieno et al. 2005). At R1, concentrations for all compounds were lowest in August when temperatures were warmest (Supplementary material S1).

\subsection{UK Estuaries}

The Humber Estuary was shown to represent a worst case scenario in terms of pharmaceutical pollution, with all five pharmaceuticals present at relatively high concentrations. Of the estuaries sampled, it was the second highest impacted by WWTPS, with a PE of approximately 13.7 million people. The Thames, which was the most impacted, was the only other estuary to contain all five compounds. A higher presence of pharmaceuticals is frequently seen in large urban areas due to their increased usage (Hong et al. 2018). With the exception of both the Humber and the Thames estuaries, there was no apparent relationship between the number of WWTP and concentrations (Table 2). The Cromarty Firth, which was the receiving water of only 3 WWTPs (15,600 PE), exhibited similar levels of pharmaceuticals to the Humber. This could be explained by differences WWTP efficiency, as technology used in WWTPs can greatly affect the removal of pharmaceuticals. For example, ibuprofen removal has been reported to be between $7 \%$ and $99 \%$ at different WWTPs (Radjenovic et al. 2007; Jelic et al. 2015). It is possible that the removal efficiency of 
This work is licensed under a Creative Commons Attribution-NonCommercial-NoDerivatives 4.0 International License.

WWTPs could differ between areas, with rural areas being less efficient as they are serving smaller populations. Rural areas are more likely to have a higher occurrence of septic tanks, which could contribute to the elevated levels seen in the Cromarty (Hanamoto et al. 2018). Whilst the Humber experienced the lowest concentration in August, it is possible that seasonal variations in population in areas like the Scottish Highlands (a tourist destination), where the Cromarty is located, could be responsible for these higher concentrations, increasing pressure on WWTPs. Pharmaceuticals in a Portuguese river have previously shown higher concentrations which was thought to be the result of increased summer populations (Rocha et al. 2014).

The presence of pharmaceuticals is greatly influenced by environmental conditions and proximity of the sampling site to input sources, possibly accounting for some of the apparent differences in concentrations observed between estuaries. Water samples from different locations in the estuary were mixed together and a subsample was taken to obtain a snapshot of the presence of pharmaceuticals, and it is likely that these concentrations will vary depending on these factors. This could possibly explain the absence of diclofenac, which in the Humber study was frequently undetected in sites downstream the estuary. Citalopram also had a low detection (50\%) in estuaries, however, it was detected in estuaries which have the highest PE.

There are also likely to be more complex interactions in play which further affect the occurrence of pharmaceuticals in estuaries and can help to explain the spatial differences seen. Differences in site specific conditions such as salinity profiles and hydrology can affect sorption processes, degradation and dilution. Undoubtedly, these processes, in conjunction with daily variations in rainfall and temperature, are likely to be responsible for differences in concentrations in estuaries between sampling periods, yet it is still clear that pharmaceutical pollution is a ubiquitous problem in estuaries (Tamtam et al. 2008).

Ibuprofen, paracetamol, diclofenac and trimethoprim were previously monitored in the Mersey, Thames, Tees and Tyne estuaries (as well as Belfast Lough) in 2002 (Thomas and Hilton, 
This work is licensed under a Creative Commons Attribution-NonCommercial-NoDerivatives 4.0 International License.

427 2004). It was also found that ibuprofen was present at highest concentrations. Paracetamol,

428 however, was not detected in any of the estuaries sampled in 2002 , which indicates that the

429 occurrence of this compound could be rising. A rise in pharmaceuticals would be consistent

430 with what has been found in other areas. For example, analysis of sediment cores in Jamaica

431 showed an overall rise in pharmaceutical concentrations over time, with these concentrations

432 doubling over the last decade (Lara-Martin et al. 2015). This highlights the importance of establishing baseline measurements of pharmaceuticals, in order to determine areas most at risk and therefore require continued monitoring. The Humber Estuary likely poses the greatest risk, particularly due to the high level concentrations of ibuprofen. Other large urban estuaries (such as the Thames and Severn) may also warrant a further detailed study. However, as seen with the Cromarty, focus on monitoring should be extended to rural areas as well.

\section{Conclusion}

All five target analytes - ibuprofen, paracetamol, diclofenac, trimethoprim and citalopram were detected in twelve estuaries in the UK. Diclofenac is a compound that has been highlighted as a potential concern, yet paracetamol and ibuprofen were consistently detected at higher concentrations and at levels which could be toxic to aquatic organisms (Vestel et al. 2016). In particular, the concentrations of ibuprofen measured indicate that the limited monitoring of pharmaceuticals in estuaries around the globe to date has not accurately quantified peak concentrations. Whilst trimethoprim was detected in every sample it was only present at concentrations in the low $\mathrm{ng} \mathrm{l}^{-1}$ range. Citalopram was present at lowest concentrations, but also showed the least change in concentration downstream the estuary. A more intensive monitoring regime of the Humber Estuary showed that pharmaceutical input from WWTPs is a significant source and could explain the overall higher concentrations of pharmaceuticals in large urban estuaries. Despite this, a rural estuary had the highest concentration of ibuprofen which may be due to lower removal at smaller rural sewage works. 
This work is licensed under a Creative Commons Attribution-NonCommercial-NoDerivatives 4.0 International License.

453 More detailed studies need to be undertaken in order to understand the complex interactions

454 taking place in estuaries which could affect the fate of pharmaceuticals.

455 Whilst there was little significant variation of pharmaceutical concentrations between sampling 456 periods in the Humber Estuary, August typically had the lowest input from WWTPs and overall 457 lowest concentrations, which is when samples were taken from estuaries throughout the UK. 458 Consequently, it could be expected that pharmaceutical concentrations may exceed those 459 measured. Additionally, samples were taken on a high tide when it would be expected that concentrations are lowest due to dilution. This study provides an important baseline of pharmaceutical measurements in the UK, and highlights ibuprofen as a compound which may warrant further assessment. This work provides further evidence to the growing problem of pharmaceutical pollution, highlighting that it is not only an urban and localised issue.

\section{Acknowledgements}

This project was primarily funded via a Natural Environmental Research Council PhD studentship (165232) to S. Letsinger. This work was also supported by water@leeds and by the European Union through the European Development Fund (ERDF) and by the Generalitat de Catalunya (Consolidate Research Group ICRA-ENV 2017 SGR 1124). S. RodriguezMozaz acknowledges the Ramon y Cajal program (RYC-2014-16707)

\section{References}

473 Alygizakis NA, Gago-Ferrero P, Borova VL, Pavlidou A, Hatzianestis I, Thomaidis NS (2016) Occurrence and spatial distribution of 158 pharmaceuticals, drugs of abuse and related metabolites in offshore seawater. Sci Total Environ 541: 1097-1105. doi: 10.1016/j.scitotenv.2015.09.145

Arpin-Pont L, Bueno MJM, Gomez E, Fenet H (2014) Occurrence of PPCPs in the marine 
This work is licensed under a Creative Commons Attribution-NonCommercial-NoDerivatives 4.0 International License. environment: a review. Environ Sci Pollut Res. 23(6):4978-91 doi: 10.1007/s11356-014$3617-x$

Aus der Beek T, Weber F, Bergmann A, Hickmann S, Ebert I, Hein A, Kuster A (2016) Pharmaceuticals in the environment - Global occurrences and perspectives. Environ. Toxicol. Chem. 35(4): 823-835 doi: 10.1002/etc.3339

Baker DR, Kasprzyk-Hordern B (2013) Spatial and temporal occurrence of pharmaceuticals and illicit drugs in the aqueous environment and during wastewater treatment: New developments. Sci Total Environ 454-455: 442-456. doi: 10.1016/j.scitotenv.2013.03.043

Bayen S, Zhang H, Desai MM, Ooi SK, Kelly BC (2013) Occurrence and distribution of pharmaceutically active and endocrine disrupting compounds in Singapore's marine environment: Influence of hydrodynamics and physical-chemical properties. Environ Poll 182: 1-8. doi: 10.1016/j.envpol.2013.06.028

Bendz D, Paxéus NA, Ginn TR, Loge FJ (2005) Occurrence and fate of pharmaceutically active compounds in the environment, a case study: Höje River in Sweden. J Hazard Mat 122: 195-204. doi: 10.1016/j.jhazmat.2005.03.012

Benotti MJ, Brownawell BJ (2007) Distriutions of Pharmaceuticals in an Urban Estuary during both Dry and Wet-Weather Conditions. Environ Sci Technol 41 (16) 5795-5802 doi: $10.1021 /$ es0629965

Birch GF, Drage DS, Thompson K, Eaglesham G, Mueller JF (2015) Emerging contaminants (pharmaceuticals, personal care products, a food additive and pesticides) in waters of Sydney estuary, Australia. Mar Poll Bull 97(1-2): 56-66

Bound JP, Voulvoulis N (2005) Household disposal of pharmaceuticals as a pathway for aquatic contamination in the United Kingdom. Environ Health Perspect 113: 17051711. doi: $10.1289 /$ ehp.8315 
This work is licensed under a Creative Commons Attribution-NonCommercial-NoDerivatives 4.0 International License.

503 Buck AL (1997) An inventory of UK estuaries - Volume 5. Eastern England Joint Nature Conservation Committee, Peterborough

505

506

507

508

509

510

511

512

513

514

515

516

517

518

519

520

521

522

Burns EE, Carter LJ, Kolpin DW, Thomas-Oates J, Boxall ABA (2018) Temporal and spatial variation in pharmaceutical concentrations in an urban river system. Wat Res doi: 10.1016/j.watres.2018.02.066

Burns EE, Thomas-Oates J, Kolpin DW, Furlong ET, Boxall ABA (2017) Are exposure predictions, used for the prioritization of pharmaceuticals in the environment, fit for purpose? Environ Toxicol Chem 36: 2823-2832. doi: 10.1002/etc.3842

Caldwell DJ (2016) Sources of Pharmaceutical Residues in the Environment and their Control. Issues in Environmental Science and Technology 41: 92-119. doi: $10.1039 / 9781782622345-00092$

Cantwell MG, Katz DR, Sullivan JC, Ho Kay, Burgess RM (2017) Temporal and spatial behaviour of pharmaceuticals in Narragansett Bay, Rhode Island, United States. Environ Chem 36 (7) 1846-1855 doi: 10.1002/etc.3710

Cantwell MG, Katz DR, Sullivan JC, Shapley D, Lipscomb J, Epstein J, Juhl AR, Knudson C, O'Mullan GD (2018) Spatial patterns of pharmaceuticals and wastewater tracers in the Hudson River Estuary. Wat Res 137: 335-343. doi: 10.1016/J.WATRES.2017.12.044

Caracciolo AB, Topp E, Grenni P (2015) Pharmaceuticals in the environment: Biodegradation and effects on natural microbial communities: A review. J Pharm Biomed Anal 106: 25-36. doi: 10.1016/j.jpba.2014.11.040

Chen H, Liu S, Xu X, Zhou G, Liu S, Yue W, Sun K, Ying G (2015) Antibiotics in the coastal environment of the Hailing Bay region, South China Sea: spatial distribution, source analysis and ecological risks. Mar Poll Bull. 95(1) 365-373 doi:10.1016/j.marpolbul.2015.04.025

Cui Y, Wang Y, Pan C, Li R, Xue R, Guo J, Zhang R (2019) Spatiotemporal distributions, 
This work is licensed under a Creative Commons Attribution-NonCommercial-NoDerivatives 4.0 International License. source apportionment and potential risks of 15 pharmaceuticals and personal care products (PPCPs) in Qinzhou Bay, South China. Mar Poll Bull 141: 104-111 doi: 10.1016/J.MARPOLBUL.2019.02.012

Davidson NC, Laffoley DD, Doody JP, Way LS, Gordon J, Key R, Pienkowski MW, Mitchell R, Duff KL (1991) Nature conservation and estuaries in Great Britain. Nature Conservancy Council, Perborough

Daughton CG (2016) Pharmaceuticals and the Environment (PiE): Evolution and impact of the published literature revealed by bibliometric analysis. Sci Total Environ 562: 391426. doi: 10.1016/j.scitotenv.2016.03.109

Dong H, Yuan X, Wang W, Qiang Z (2016) Occurrence and removal of antibiotics in ecological and conventional wastewater treatment processes: A field study. J Environ Manage 178: 11-19. doi: 10.1016/j.jenvman.2016.04.037

Eades C, Waring CP (2010) The effects of diclofenac on the physiology of the green shore crab Carcinus maenas. Mar Environ Res 69: S46-S48. doi: 10.1016/j.marenvres.2009.11.001

Ebele AJ, Abou-Elwafa Abdallah M, Harrad S (2017) Pharmaceuticals and personal care products (PPCPs) in the freshwater aquatic environment. Emerging Contaminants 3: 116. doi: 10.1016/J.EMCON.2016.12.004

Environment Agency (2019) Catchment Data Explorer. Available from: https://environment.data.gov.uk/catchment-planning/ (January 8, 2019).

European Environment Agency (2017) Urban Waste Water Treatment Map. Available from: https://www.eea.europa.eu/themes/water/european-waters/water-use-andenvironmental-pressures/uwwtd/interactive-maps/urban-waste-water-treatment-maps. (March 15, 2019)

Fabbri E, Franzellitti S (2016) Human pharmaceuticals in the marine environment: Focus on 
This work is licensed under a Creative Commons Attribution-NonCommercial-NoDerivatives 4.0 International License. exposure and biological effects in animal species. Environ Toxicol Chem 35: 799-812. doi: 10.1002/etc.3131

Franzellitti S, Buratti S, Valbonesi P, Fabbri E (2013) The mode of action (MOA) approach reveals interactive effects of environmental pharmaceuticals on Mytilus galloprovincialis. Aquat Toxicol 140-141: 249-256. doi: 10.1016/j.aquatox.2013.06.005

Gaw S, Thomas K V, Hutchinson TH (2014) Sources, impacts and trends of pharmaceuticals in the marine and coastal environment. Philosoph Trans Royal Soc B 369. doi: 10.1098/rstb.2013.0572

Godoy AA, Kummrow F, Pamplin PAZ (2015) Occurrence, ecotoxicological effects and risk assessment of antihypertensive pharmaceutical residues in the aquatic environment - $\mathrm{A}$ review. Chemosphere 138: 281-291. doi: 10.1016/j.chemosphere.2015.06.024

Golovko O, Kumar V, Fedorova G, Randak T, Grabic R (2014a) Removal and seasonal variability of selected analgesics/anti-inflammatory, anti-hypertensive/cardiovascular pharmaceuticals and UV filters in wastewater treatment plant. Environ Sci Pollut Res 21: 7578-7585 doi:10.1007/s11356-014-2654-9

Golovko O, Kumar V, Fedorova G, Randak T, Grabic R (2014b) Seasonal changes in antibiotics, antidepressants/psychiatric drugs, antihistamines and lipid regulators in a wastewater treatment plant. Chemosphere 111: 418-426. doi: 10.1016/j.chemosphere.2014.03.132

Gonzalez-Rey M, Tapie N, Menach KL, Dévier MH, Budzinski H, Bebianno MJ (2015) Occurrence of pharmaceutical compounds and pesticides in aquatic systems. 96(1-2): 384-400 doi:10.1016/j.marpolbul.2015.04.029

Gros M, Rodríguez-Mozaz S, Barceló D (2012) Fast and comprehensive multi-residue analysis of a broad range of human and veterinary pharmaceuticals and some of their metabolites in surface and treated waters by ultra-high-performance liquid 
This work is licensed under a Creative Commons Attribution-NonCommercial-NoDerivatives 4.0 International License. chromatography coupled to quadrupole-linear ion trap tandem. Jo Chromat A 1248: 104-121. doi: 10.1016/j.chroma.2012.05.084

Guo J, Sinclair CJ, Selby K, Boxall ABA (2016) Toxicological and ecotoxicological risk-based prioritization of pharmaceuticals in the natural environment. Environ Toxicol Chem 35 (6): 1550-1559 doi: 10.1002/etc.3319

Hanamoto S, Nakada N, Yamashita N, Tanaka H (2018) Source estimation of pharmaceuticals based on catchment population and in-stream attentuation in Yodo River Watershed, Japan. Sci Total Environ 615: 964-971 doi: 10.1016/J.SCITOTENV.2017.10.013

Hong B, Lin Q, Yu S, Chen Y, Chen Y, Chiang P (2018) Urbanization gradient of selected pharmaceuticals in surface water at a watershed scale. Sci Total Environ 634: 448458. doi: 10.1016/J.SCITOTENV.2018.03.392

Hughes SR, Kay P, Brown LE (2013) Global synthesis and critical evaluation of pharmaceutical data sets collected from river systems. Environ Sci Technol 47: 661677. doi: $10.1021 / \mathrm{es} 3030148$

Jelic A, Rodriguez-Mozaz S, Barceló D, Gutierrez O (2015) Impact of in-sewer transformation on 43 pharmaceuticals in a pressurized sewer under anaerobic conditions. Wat Res 68: 98-108. doi: 10.1016/j.watres.2014.09.033

Kantor ED, Rehm CD, Haas JS, Chan AT, Giovannucci EL (2015) Trends in Prescription Drug Use Among Adults in the United States From 1999-2012. JAMA 314: 1818. doi: 10.1001/jama.2015.13766

Kasprzyk-Hordern B, Dinsdale RM, Guwy AJ (2007) Multi-residue method for the determination of basic/neutral pharmaceuticals and illicit drugs in surface water by solid-phase extraction and ultra performance liquid chromatography-positive electrospray ionisation tandem mass spectrometry. J Chromat A 1161: 132-145. doi: 
This work is licensed under a Creative Commons Attribution-NonCommercial-NoDerivatives 4.0 International License. 10.1016/J.CHROMA.2007.05.074

604

Kasprzyk-Hordern B, Dinsdale RM, Guwy AJ (2008) The removal of pharmaceuticals, personal care products, endocrine disruptors and illicit drugs during wastewater treatment and its impact on the quality of receiving waters. Wat Res 42 (13): 3498-3518 doi: 10.1016/j.watres.2008.10.047

Kay P, Hughes SR, Ault JR, Ashcroft AE, Brown LE (2017) Widespread, routine occurrence of pharmaceuticals in sewage effluent, combined sewer overflows and receiving waters. Environ Poll 220: 1447-1455 doi: 10.1016/j.envpol.2016.10.087

Klosterhaus SL, Grace R, Hamilton MC, Yee D (2013) Method validation and reconnaissance of pharmaceuticals, personal care products, and alkylphenols in surface waters, sediments, and mussels in an urban estuary. Environ Int 54: 92-99

Kunkel U, Radke M (2012) Fate of pharmaceuticals in rivers: Deriving a benchmark dataset at favorable attenuation conditions. Wat Res. 46(17): 5551-5565 doi: 10.1016/J.WATRES.2012.07.033

Lara-Martín PA, González-Mazo E, Petrovic M, Barceló B (2014) Occurrence, distribution and partitioning of nonionic surfactants and pharmaceuticals in the urbanized Long Island Sound Estuary (NY). Mar Poll Bull 85: 710-719 doi: 10.1016/J.MARPOLBUL.2014.01.022

Lara-Martín PA, Renfro A, Cochran J, Brownawell B (2015) Geochronologies of pharmaceuticals in a sewage-impacted estuarine urban setting (Jamaica Bay, New York). Environ Sci Technol. 49(10) 5948-5955 doi: 10.1021/es506009v

Li WC (2014) Occurrence, sources, and fate of pharmaceuticals in aquatic environment and soil. Environ Poll 187: 193-201. doi: 10.1016/j.envpol.2014.01.015

Ma R, Wang B, Yin L, Zhang Y, Deng S, Huang J, Wang Y, Yu G (2017) Characterization of pharmaceutically active compounds in Beijing, China: Occurrence pattern, 
This work is licensed under a Creative Commons Attribution-NonCommercial-NoDerivatives 4.0 International License. spatiotemporal distribution and its environmental implication. J Hazard Mat 323: 147155. doi: 10.1016/J.JHAZMAT.2016.05.030

Madureira TV, Barreiro JC, Rocha MJ, Rocha E, Cass QB, Tiritan ME (2010) Spatiotemporal distribution of pharmaceuticals in the Douro river estuary. Sci Total Environ 408(22):5513-5520

Mavragani A, Sypsa K, Sampri A, Tsagarakis K (2016) Quantifying the UK Online Interest in Substances of the EU Watchlist for Water Monitoring: Diclofenac, Estradiol, and the Macrolide Antibiotics. Water 8: 542. doi: 10.3390/w8110542

Metcalfe CD, Chu S, Judt C, Li H, Oakes KD, Servos MR, Andrews DM (2010) Antidepressants and their metabolites in municipal wastewater, and downstream exposure in an urban watershed. Environ Toxicol Chem 29: 79-89. doi: 10.1002/etc.27

Mijangos L, Ziarrusta H, Ros O, Kortazar L, Fernández LA, Olivares M, Zuloaga O, Prieto A, Extebarria N (2018) Occurrence of emerging pollutants in estuaries of the Basque Country: analysis of sources and distribution, and assessment of the environmental risk. Wat Res. 147: 152-163 doi:10.1016/j.watres.2018.09.033

Minguez L, Pedelucq J, Farcy E, Ballandonne C, Budzinski H, Halm-Lemeille M-P (2016) Toxicities of 48 pharmaceuticals and their freshwater and marine environmental assessment in northwestern France. Environ Sci Pollut Res Int 23(6): 4992-5001 doi: $10.1007 / \mathrm{s} 11356-014-3662-5$

Moreno-González R, Rodríguez-Mozaz S, Gros M, Pérez-Cánovas E, Barceló D, León VM (2014) Input of pharmaceuticals through coastal surface watercourses into a Mediterranean lagoon (Mar Menor, SE Spain): Sources and seasonal variations. Sci Total Environ 490: 59-72. doi: 10.1016/j.scitotenv.2014.04.097

Munro K, Martina CPB, Loewenthal M, Comber S, Cowan DA, Pereira L, Barron LP (2019) Evaluation of combined sewer overflow impacts on short-term pharmaceutical and illicit 
This work is licensed under a Creative Commons Attribution-NonCommercial-NoDerivatives 4.0 International License.

653

654

655

656

657

658

659

660

661

662

663

664

665

666

667

668

669

670

671

672

673

674

675

676

677 drug occurrence in a heavily urbanised tidal river catchment (London, UK). Sci Total Environ 657: 1099-1111 doi: 10.1016/j.scitotenv.2018.12.08

Nakada N, Hanamoto S, Jürgens MD, Johnson AC, Bowes MJ, Tanaka H (2017) Assessing the population equivalent and performance of wastewater treatment through the ratios of pharmaceuticals and personal care products present in a river basin: Application to the River Thames basin, UK. Sci Total Environ 575: 1100-1108. doi: 10.1016/J.scitotenv.2016.09.180

National Health Service (2017) Prescriptions Dispensed in the Community - Statistics for England, 2006-2016. Available from: https://digital.nhs.uk/data-andinformation/publications/statistical/prescriptions-dispensed-in-thecommunity/prescriptions-dispensed-in-the-community-statistics-for-england-2006-2016pas (January 1, 2019).

National Health Service (2019) Prescriptions Dispensed in the Community - NHS Digital. Available from: https://digital.nhs.uk/data-andinformation/publications/statistical/prescriptions-dispensed-in-the-community (January 8, 2019).

Ort C, Lawrence MG, Reungoat J, Mueller JF (2010) Sampling for PPCPs in Wastewater Systems: Comparison of Different Sampling Modes and Optimization Strategies. Environ Sci Technol 44: 6289-6296 doi: 10.1021/es100778d

Paíga P, Santos LHMLM, Ramos S, Jorge S, Silva JG, Delerue-Matos C (2016) Presence of pharmaceuticals in the Lis river (Portugal): Sources, fate and seasonal variation. Sci Total Environ 573: 164-177. doi: 10.1016/J.SCITOTENV.2016.08.089

Pohlert T (2014) The pairwise multiple comparison of mean ranks package (PMCMR). Available from: https://cran.r-project.org/package=PMCMR (October 12, 2018).

Radjenovic J, Petrovic M, Barceló D (2007) Analysis of pharmaceuticals in wastewater and 
This work is licensed under a Creative Commons Attribution-NonCommercial-NoDerivatives 4.0 International License.

678 removal using a membrane bioreactor. Anal Bioanal Chem 387: 1365-1377. doi: $10.1007 / \mathrm{s} 00216-006-0883-6$

Redshaw CH, Stahl-Timmins WM, Fleming LE, Davidson I, Depledge MH (2013) Potential Changes in Disease Patterns and Pharmaceutical Use in Response to Climate Change. J Toxicol Environ Health B 16: 285-320. doi: 10.1080/10937404.2013.802265

Reis-Santos P, Pais M, Duarte B, Cacador I, Freitas, A, Pouca ASV, Barbosa J, Leston S, Rosa J, Ramos F, Cabral HN, Gillanders BM, Fronseca VF (2018) Screening of human and veterinary pharmaceuticals in estuarine waters: A baseline assessment for the Tejo estuary. Mar Poll Bull 135: 1079-1084. doi:10.1016/j.marpollbul.2018.08.036

Ridgway J, Shimmield G (2002) Estuaries as Repositories of Historical Contamination and their Impact on Shelf Seas. Estuar Coast Shelf Sci 55: 903-928. doi: 10.1006/ECSS.2002.1035

Roberts PH, Thomas K V. (2006) The occurrence of selected pharmaceuticals in wastewater effluent and surface waters of the lower Tyne catchment. Sci Total Environ 356: 143153. doi: 10.1016/j.scitotenv.2005.04.031

Roos V, Gunnarsson L, Fick J, Larsson DGJ, Rudén C (2012) Prioritising pharmaceuticals for environmental risk assessment: Towards adequate and feasible first-tier selection. Sci Total Environ 421 (102-110) doi: 10.1016/j.scitotenv.2012.01.039.

Santos LHMLM, Araújo AN, Fachini A, Matos-Delerue PC, Montenegro MCBSM (2010) Ecotoxicological aspects related to the presence of pharmaceuticals in the aquatic environment. J Hazard Mat. 175: 45-95 doi: 10.1016/j.jhazmat.2009.10.100

Styrishave B, Halling-Sørensen B, Ingerslev F (2011) Environmental risk assessment of three selective serotonin reuptake inhibitors in the aquatic environment: a case study including cocktail scenario. Environ Toxicol Chem 30: 254-261. Available from: 10.1002/etc.372. 
This work is licensed under a Creative Commons Attribution-NonCommercial-NoDerivatives 4.0 International License.

Sun Q, Li Y, Li M, Ashfaq M, Lv M, Wang H, Hu A, Yu C (2016) PPCPs in Jiulong river estuary (China): spatiotemporal distributions, fate and their use as chemical markers of wastewater. Chemosphere 150: 596-604. doi:10/1016/j.chemosphere.2016.02.036

Tamtam F, Mercier F, Le Bot B, Eurin J, Tuc Dinh Q, Clement M, Chevreuil M (2008) Occurrence and fate of antibiotics in the Seine River in various hydrological conditions. Sci Total Environ 393 (1): 84-95. doi:10.1016/j.scitotenv.2007.12.009

Thomas K V, Hilton MJ (2004) The occurrence of selected human pharmaceutical compounds in UK estuaries. Mar Poll Bull 49: 436-444. doi: 10.1016/j.marpolbul.2004.02.028

Verlicchi P, Zambello E (2016) Predicted and measured concentrations of pharmaceuticals in hospital effluents. Examination of the strengths and weaknesses of the two approaches through the analysis of a case study. Sci Total Environ 565: 82-94. doi: 10.1016/j.scitotenv.2016.04.165

Vestel J, Caldwell DJ, Constantine L, D'Aco VJ, Davidson T, Dolan DG, Millard SP, MurraySmith R, Parke NJ, Ryan JJ, Straub JO, Wilson P (2016) Use of acute and chronic ecotoxicity data in environmental risk assessment of pharmaceuticals. Environ Toxicol Chem 35: 1201-1212. doi: 10.1002/etc.3260

Vieno NM, Tuhkanen T, Kronberg L (2005) Seasonal Variation in the Occurrence of Pharmaceuticals in Effluents from a Sewage Treatment Plant and in the Recipient Water. Environ Sci Technol 39: 8220-8226. doi: 10.1021/es051124k

Weigel S, Kuhlmann J, Hühnerfuss H (2002) Drugs and personal care products as ubiquitous pollutants: occurrence and distribution of clofibric acid, caffeine and DEET in the North Sea. Sci Total Environ 295(1-3): 131-141. doi:10.1016/S0048=9697(02)00645

Wickham H (2016) ggplot2; Elegant Graphics for Data Analysis. Available from: 
This work is licensed under a Creative Commons Attribution-NonCommercial-NoDerivatives 4.0 International License.

Wilkinson JL, Hooda PS, Swinden J, Barker J, Barton S (2017) Spatial distribution of organic contaminants in three rivers of Southern England bound to suspended particulate material and dissolved in water. Sci Total Environ 593-594: 487-497. doi: 10.1016/J.SCITOTENV.2017.03.167

Xu W, Zhang G, Zhou S, Li X, Liu Y (2007) Determination of selected antibiotics in the Victoria Harbour and the Pearl River, South China using high-performance liquid chromatography-electrospray ionization tandem mass spectrometry. Environ. Poll. 145: 672-679 doi: 10.1016/j.envpol.2006.05.038

Yang Y, Fu J, Peng H, Hou L, Liu M, Zhou JL (2011) Occurrence and phase distribution of selected pharmaceuticals in the Yangtze estuary and its coastal zone. J Hazard Mat 190(1-3): 588-596 doi;10.1016/jhazmat.2011.03.092

Yang Y, Cheng Q, Lin L, Wang X, Chen B, Luan T, Tam N (2016) Partitions and vertical profiles of 9 endocrine disrupting chemicals in an estuarine environment: Effect of tide, particle size and salinity. Environ Poll. 211: 58-66 doi: 10.1016/j.watres.2016.05.048

Zhang R, Zhang G, Zheng Q, Tang J, Chen Y, Xu W, Zou Y, Chen X (2012) Occurrence and risks of antibiotis in the Laizhou Bay, China: impacts of river discharge. Ecotox Environ Safe 80: 208-215 doi:10.1016/j.ecoenv.2012.03.002

Zhao H, Zhou JL, Zhang J (2015) Tidal impact on the dynamic behaviour of dissolved pharmaceuticals in the Yangtze estuary, China. Sci Total Environ. 536: 946-954 doi:10.1016/j.scitotenv.2015.06.055 